\title{
Rājādhirāt: From the History to an Influential literature for Mon-accented Thai traditional Repertoires
}

\author{
Assistant Professor Jarun Kanchanapradit \\ Department of Music, Faculty of Fine and Applied Arts, Khon Kaen University \\ Wanida Bhrammaputra \\ Khon Kaen University Demonstration Elementary School (Education)
}

\begin{abstract}
This article aimed to study Mon-accented Thai traditional repertoires through Rājādhirāt literature, which owe its origin from the Chronicles of the Mon. It is the story about the battle between the king Rājādhirāt of Pegu and King Farang Mang Kong of Ava. The translated Thai language prose version was arranged by Chao Phraya Phra Khlang (Hon), a poet master during King Rama I. Later during King Rama V, the Rājādhirāt was adapted for theatrical play - Lakorn Pan Tang - leading to development in musical front in order to assign appropriate Mon-accented musical pieces for the characters, their expressions, and story. Anthropologically, Rājādhirāt Literature was not only an entertainment, but also a revival of Mon-accented Thai traditional repertoires which have been associated with the Thai society for so long. The repertoires served as a reminder of once-flourishing Mon history through literature, play, music. Analysis of historical evidence, concerned persons such as the translator of Rājādhirāt from Burmese to Thai language, experienced Thai musician who played and assigned the repertoires; and expressive interpretation of musical repertoires from Rājādhirāt play by the Fine Arts Department are the integral process that made this article present another perspectives of Mon-accented Thai traditional repertoires while featuring relationship between literature, play and music in Thailand.
\end{abstract}

Keywords: the rājādhirāt, mons, literature, mon-accented thai traditional repertoires

\section{BACKGROUND AND HISTORY OF RĀJĀDHIRĀT LITERATURE}

Ràjādhirāt was a great Mon king in the past who ruled Haøsavatī city, earlier known as Pegu, located South of Burma. Meanwhile around 1385 - 1423 A.D., Ava city, located north of Pegu city, began to regain their power after the Mongol's attack on Pagán city which eventually led to its fall in 1287 A.D. (Emmanuel Guillon, 1999: 155-157). The decline of Burma also saw the rise of southern Mon Empire expanding its realm and taking control of every pier and trade centers in the South. To prevent any Mon's further growth, the Ava's Ruler of Pagán wanted to subsidize the Mon Empire for the commercial as well as political purpose by extending his power southwards, causing the subsequent wars between Burma and Mon.

One of the longest-lasting wars between Burma and Mon are well known by Burmese historians as "The 40 Year War" (Wirach Niyomdharma, 2009: 4), which 
was a battle of the Rājādhirāt,

King of Ha®savatī (Mon), against Farang Mangsrijava, also known as Mangkri Chawchowkaew, and Farang Mangong, two respective kings of Burma.

The story of Rājāahirāt has been spread and passed down to later generations in the form of the Chronicles of the Mon. It is believed that the original manuscripts of Mon language version were written on palm leaf scriptures between the reign of Queen Shin Saw bu (1453 - 1472) and King Dharmaceti (1472 - 1492). They were later reproduced and translated to Burmese by a Mon chief official Phya Thala, who was also an accomplished poet and the comrade of King Bayinnaung of Tong-U dynasty. (1550 - 1581) The literary version of Rājādhirāt written by Phya Thala was presented to honor King Bayinnaung under the title "RAZADARIT AYEDAWPON". It is a historically precious work of art with such linguistic beauty that it was regarded as National Literature by Burmese novelists, resulting in countless times of republishing - both in Mon and Burmese language - with earliest copies of rearranged version dating back to 1753 and 1757 A.D. ${ }^{1}$ (Wirach Niyomdharma, 2009: 1-4). Holliday (1969) also claimed that the Burmese language version of RAZADARIT AYEDAWPON was translated into Mon language even before 1740 A.D. by a Mon Buddhist monk named Ven. A-Foh, who was both well-versed with both Burmese and Mon languages, making the RAZADARIT AYEDAWPON available in two versions, i.e. Mon language and Burmese language.

The prevailing Mon Language version of Rājādhirāt in Burma appeared in 5 different styles. Out of these, the Pāklat edition is one of the outstanding style that used to be published in Mon language once in Thailand in 1910 A.D. and twice in Burma in 1958 A.D. and 2003 A.D., respectively. Later, Nai Pan Hla translated the Burmese language version to Mon language, thus adding another styles, and published them in 1977 A.D. and 1997 A.D.

When considering the time period that the Rājādhirāt literature has been introduced to Thailand, there was a conjecture that both versions of Rājādhirāt Mon language of Phya Thala, also known as RAZADARIT AYEDAWPON, and Burmese language version of Ven. A-Foh - was brought into Thailand along with Mon immigrants from Burma since Krungsri Ayudhya to early Rattnakosin era. However, the Mon people favored the Ven. A-Foh version. Anyway, the original manuscript of Rājādhirāt, both Mon and Burmese language, has disappeared during a war in 1757 A.D., leaving behind only its original copies. (Pisan Boonphook: 2015, Interview).

Since Mon and Thai people share close relationship between each other, the bond accelerated the spreading of the literature across Thailand and ultimately into the royal court. Rājādhirāt was selected as one of the royal literatures and was translated and rearranged into prose by royal novelists, Chao Phraya Phra Khlang 
(Hon) and 3 other colleagues during King Phra Phutthayotfa Chulalok Great. The edition was complete in 1785 A.D. before it was published for the first time by Bradley's Press in 1880.

From the study of Bussaba Trakulsajjawatra (1986) under the title "Analytical study of Rājādhirāt literature by Chao Phraya Phra Khlang (Hon)", it was conjectured that this edition of Rājādhirāt could possibly be compiled from at least 4 various sources, i.e. RAZADARIT AYEDAWPON of Phraya Thala, 2) the Dharma Chedi tales, 3) Royal Chronicles of Pago, written by Ven. A-Foh and 4) Raman Yupatidipak, written by a Monk of Zingyaik. Moreover, Bussaba Trakulsajjawatr (1986: 22) has further concluded that there were 4 original chronicles that mentioned the biography of King Rājādhirāt, namely:

1) RAZADARIT AYEDAWPON of Phraya Thala language

2) Rājādhirāt by Chao Phraya Phra Khlang (Hon)

3) Chroicles of the Mon by Pāklat $1^{\text {st }}$ volume

4) Rājādhirāt by Nai Pan Hla
Written in Burmese

Written in Thai language Written in Mon language Written in Mon language

In addition to these findings, the supplement studies revealed that there were other 2

Thai editions of Rājādhirāt, written in the form of chronicle, which was approved officially. One is Rājādhirāt Yuddhna: Phya Thala edition written by Virach Niyomdharm (2009). It was translated from a Burmese book "Myanmar Raja Yuddhyakar" (MYANMA MONG MYA AYENG TER PER), published in 1967 (Virach Niyomdharm, 2013: Interview). The other is "The Sacred Pagodas and Shrines of the Mon People" written by Prakru Jotidharmasundar (2006 A.D.). The latter is a compilation of documents pertaining to the legend of Shwedagon pagoda in which the King Rājādhirāt was mentioned for restoration of the pagoda.

After the prose edition of Rājādhirāt literature, written by a master poet Chao Phraya Phra Khlang (Hon), was publicized to Thai society during the King Phra Phutthayotfa Chulalok the Great, it was so well received that several reproductions were requensted. Ultimately, the literature was adapted for two new branches of art works, i.e. play and music. The latter, in particular, is in the form of musical suite called Tub Rājādhirāt. It is performed to accompany Tableaux Vivants.

It is, therefore, fair to state that Chao Phraya Phra Khlang (Hon)'s version of Rajjādhirāt is the work that stimulated creation of Thai theatrical plays whose impact also led to creation of Thai musical works as well.

\section{From Thai Literature to Thai Play}

Theatrical play in Thailand is a branch of performing arts that was systematically developed, combining together literary arts, choreographic arts, visual arts and musical arts. (Chakrit Duangpatra, 2001: 1) During the reign of King Rama V, a 
new form of theatrical play - Lakorn Pan Tang (the hybrid play) - was invented from the existing dancing play. The Lakorn Pan Tang's significant characteristics are the ethnically diverse characters and its stories were adopted from domestic and international historical literatures. For examples, Rājādhirāt was adopted from the Mon's chronicles, Sam Kok (Romance of the Three Kingdoms) from history-based Chinese literature, Pra Lor from the story of the war between Chiang Mai and Ayuddhya and Phu Jana Sib Thid from a novel based on biography of King Berengnong of Burma.

There were 2 popular play troupes in the reign of King Rama V. The first was the troupe of Chaophraya Mahindrashaktidhamrong (Peng Penkul), who was also the owner of a theatre called "Prince Theatre". Luang Pattanapongbhakdi (Tim Sukyang) was the troupe's playwright. The troupe usually performed what is known as "Lakorn Pasom Samakhi" (united mixed play). The other was the "Naruemitr play troupe" of Prince Worawannakorn. The latter played a key role in creating Lakorn Pan Tang. Chaochommanda Khien and Mom Tuan Worawan were 2 instrumental playwrights for Naruemitr troupe (Saowanit Wingwon, 2012: 101-106). The idea of developing Lakorn Pan Tang was conceptually based on the Western play in terms of background, theatre, costumes and music. Also, most of the patterns of plays invented then became the foundation for many following theatrical creations in Thai society.

Taking Rājādhirāt into account, it is found that the troupe of Chaophraya Mahindrashaktidhamrong (Peng Penkul) pioneered the adoption of Chao Phraya Phra Khlang (Hon)'s version of Rājādhirāt into a theatrical play. Luang Pattanapongbhakdi (Tim Sukyang) was again the playwright for this very play by transforming the literary forms of the original Rājādhirāt in such a way that Chakrit Duangpatra (2001) described it as "the abridging, linking both prose and poem while assigning suitable repertoires to form dancing play/dialogue play" Chakrit Duangpatra (2001: 119). On the other hand, Rājādhirāt has been rearranged for Lakorn Pan Tang as well, undergoing 2 phases of developments. The first was translating the original Chronicles of the Mon, arranging them into prose using.

Chao Phraya Phra Khlang (Hon)'s literary style. The second was rearranging the prose into a play script for Lakorn Pan Tang.

\begin{tabular}{|c|}
$\begin{array}{c}\text { Chronicles of the } \\
\text { Mon Rājādhirāt } \\
\text { (Mon - Burmese } \\
\text { Language) } \\
\text { Ayuddhaya Era } \\
\text { (Historical } \\
\text { evidence) }\end{array}$ \\
(Novel) \\
(Dance-Music) \\
Khìādhirāt Literature \\
Chao Phraya Phra \\
(Thai language) \\
King Rama I
\end{tabular}

Illustration procedures of creating play script from chronicle 
Examples of prose to poem conversion (Saowanit Wingwon, 2555: 278)

Prose [Chao Phraya Phra Khlang (Hon)] ...Laew Thod Pra Net Do Sming Nakhon In. Trad Wa Sming Nakhon Ni Roop Ngam Som Kuan Pen Tabaan Me Lak Sa Na Sad Sue. Haa Pu Samer Pen An Yag... Poem [Luang Pattanapongbhakdi (Tim Sukyang)]

Laew Chai Net Tad Sa Na Ma Ra Yatr Do Ong Ard Id Sa Ra Ngam Cha Rit Do Naa Chom Som Chue Lueang Lue Rit Thang Nam Chit Fee Mue Chue Ngam Summary And after casting his eyes on Saming Nakon In, He (Somdej Pra Ramesuan) uttered, out of contentment, praise for Sming Nakhon In's unrivalled beautiful soldier-like physique.

Regarding the history of Rājādhirāt play, Dhanit Yupoh (1952) has organized the train of events of the Rājādhirāt play's origin. He stated that there were handwritten version and published version of the play. The latter was published by Thai Press, located at Yod Se bridge around 1914-1915, expanding 3 volumes. Later on, series of sequels are added to, from Praya Noi's escape from Pegu (Haøsavatī) to Dagon (Yangon); to Sming Pra Ram's return from Ava to Haøsavatī . Dhanit observed that these sequels could probably be the work of Luang Pattanapongbhakdi (Tim Sukyang), written for Chaophraya Mahindrashaktidhamrong (Peng Penkul)'s theatrical troupe. Also the sequels were adapted for Phraya Pechrpranee (Kree)'s Li-Ge (॰๐॰๐) performance and for Chaokun Prayurwong's theatrical play. These sequels were so popular that the Fine Arts Department included them as part of the play after its refinement.

After Rājādhirāt Lakorn Pan Tang was promoted to public attention, it saw continuously considerable public reception and even more so when Fine Arts Department came up with the refined version of the play under the supervision of Dhanit Yupoh. Premiered in 1952, the refined version of Rājādhirāt play was based on the original work of Chaophraya Mahindrashaktidhamrong (Peng Penkul) (Patnee Promsombut, 2558: Interview), along with dividing the whole play into short and terse episodes for the convenience of audience. Some of

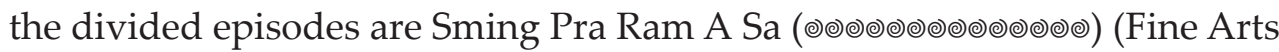

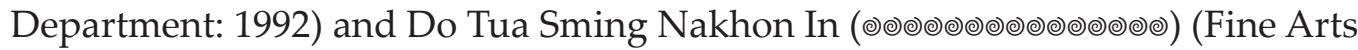
Department: 1980)

The Fine Arts Department has taken several factors into account during refinement of Rājādhirāt play, such as continuity, assigning vocal in instrumental music accompaniment. Each musical piece was selected carefully to match the ethnic background of each character. Lyrics are adjusted so that it is musically coherent for perfect expression. Furthermore, many details were standardized to make the play as much realistic and close to the original literature as possible such as backdrops, ambience and character management. Musically, vocal and instrumental repertoires were determined while conserving the classical aspects of theatrical music, i.e. Rong, Rai, Cheracha, Khaba Sebha and Nahpat Prakob Kiriya (Pattanee Promsombut, 2015: Interview) 


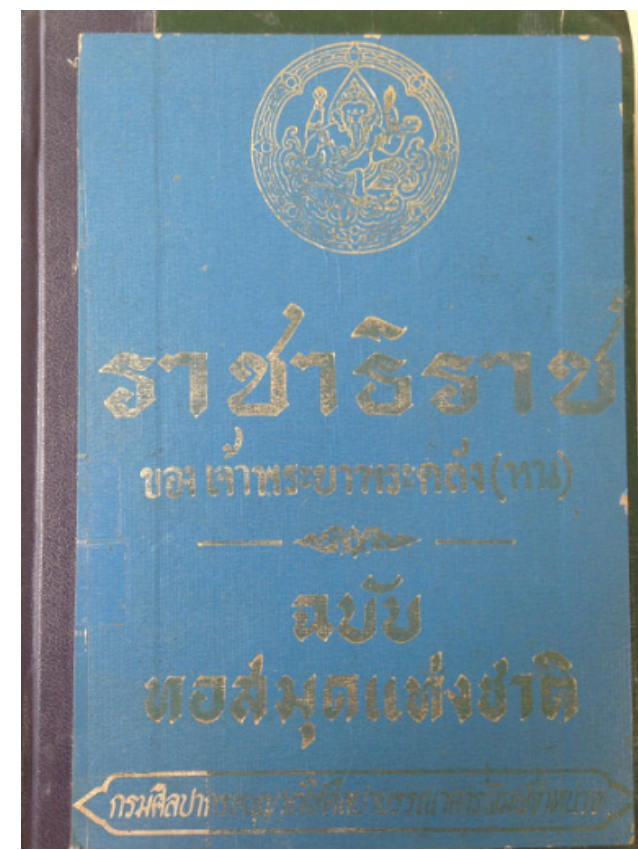

Rājādhirāt Literature by Chao Phraya Phra Khlang (Hon), Fine Arts Department, 1969

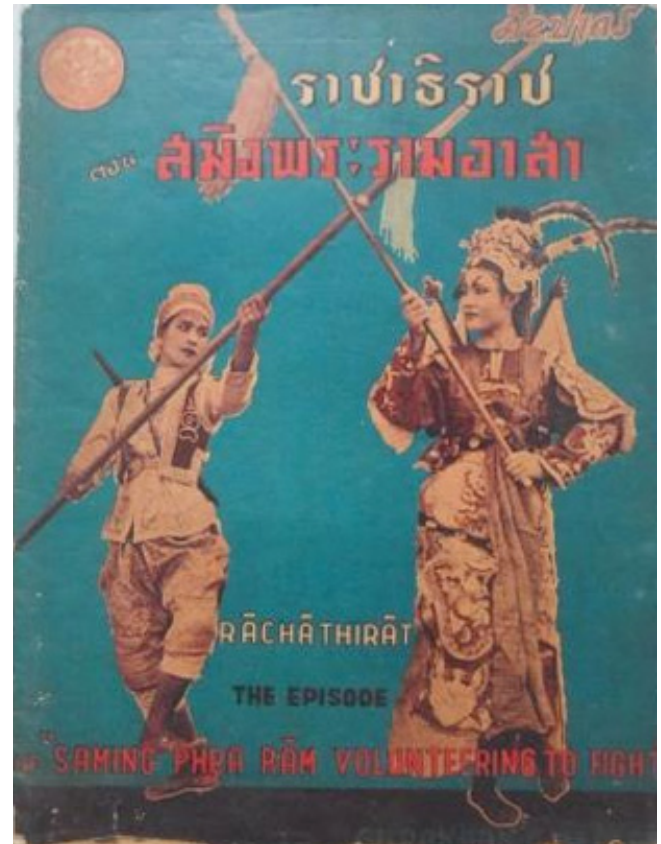

Program note of Lakorn Pan Tang "Rājādhirāte" : Sming Pra Ram A Sa, Fine Arts Department, 1952

\section{Impact of Rājādhirāt Literature on Thai Traditional Music}

Any musical progress influenced by the Rājādhirāt can be said to happen hand in hand with the development of theatrical play. After the Chao Phraya Phra Khlang (Hon)'s prose edition of Rājādhirāt was made available, paving way for Lakorn Pan Tang evolution, the theatrical play of Rājādhirāt was invented and sent its consequent impact to musical field, i.e. the birth of idiomatic or accented Thai traditional repertoires such as Burmese-accented, Chinese-accented, and Monaccented repertoires.

It is the process of assigning the lyrics to the existing musical piece that exhibits musical development as this again brought about the new types of musical works, i.e. vocal and instrumental repertoires.

\section{Development of Vocal Repertoire}

Vocal repertoires in Lakorn Pan Tang are mostly Song-Chan Repertiores and Chan-Dio Repertiores. The creation of lyrics for a musical piece involves the invention of lyrics itself and vocal melody. Both of them start from conversion of the original prose version of Rājādhirāt literature to poem. Pattanee Promsombut (2558: Interview), a playwright and musical expert gave her opinion that "when creating lyrics for a theatrical play, one must consider the appropriateness between 4 elements, i.e. story-lyrics-melody-expression. So, the lyrics writer must be experienced enough to understand the importance of these 4 elements in order to create a seamless lyrics that combine every theatrical dimensions." Apart from this, she also gave an example that "sometimes when lyrics exceeds melody or lyrics intonation does not match 
the corresponding melody, the lyrics have to be corrected." Following is an example of prose to poem conversion for Lakorn Pan Tang Rājādhirāt: Sming Pra Ram A Sa, performed by the Fine Arts Department in 1952.

\title{
Extract from Chao Phraya Phra Khlang (Hon)'s prose edition of Rājādhirāt
}

\author{
Fai Sming Pra Ram Kor Klab Ma Ti Yu. Chueng Khian Nang Sue Song Cbbab \\ Chbab Nueng Saun Wai Tai Mon. Chbab Nueng Neb Phok. Wai. Laew Kid Pen Huang Aa \\ Lai Butr Lae Ti Da. Laew Hak Chit Khom Long Dai. Mi Dai Bok Phu Dai. Pra Rad Cha \\ Nad Da An Pen Ti Rak Nan Kor Mi Chaeng Hair Ru. Klua Cha Ham Pram Khad Kwang. \\ Kwam Cha Sab Thueng Pra Chao Fa Rang Mang Khong. Chueng Ao Bang Hian Ma Phook \\ Ma Sueng Kee Su Kab Kamanee Nan. Laew Chad Chaeng Taeng Kai Nung Hom Sed. Thue \\ Tuan Sa Pai Daab Pen Khuen Lang Ma Khuab Nu Chak Muang Ang Va
}

Chao Phraya Phra Khlang (Hon), (1969: 260)

\section{Lyrics of Mon Rong Hai, written by Prince Narisara Nuvadtivongs.}

Yib Kra Dad Wad Ak Sorn Cha On Sang $\quad$ Nam Ta Lang Lai Yod Rod Ak Sorn

Laew Sod Wai Tai Khnei Ti Nang Non

Pid Pak Thod Thon Rue Thai

Khoi Tra Bom Lom Lub Chub Sang La

Nang Cha Ru Ka Ya Kor Ha Mai

Hak Chit Ok Nok Hong Tan Dai

Khuen Ma Khuab Nee Pai Mi Dai Cha

Summary: Saming Pra Ram scribbled two identical notes. One was hidden under a pillow for his children while the other was kept with him. Although very concerned about the plight of his young ones, he refused to converse, fearing that they would forbid his escape and King Farang Mang Kong would eventually got wind of it.

Comparing the original prose and composed poem, it can be seen that the poem is entirely conserving every essential information present in the prose, e.g. character, action, place and time. But on top of that, some extra features that the poem offers is the conciseness and expression that can be easily perceived by audience.

The above example lyrics of Mon Rong Hai was written by Prince Narisara Nuvadtivongs and was part of a musical suite called "Tab Rājādhirāt". The suite was arranged to accompany Tableaux Vivants in 1984 (Montri Tramote: 1980). The so arranged Rajadhitaj musical suite was also influenced by the literary work of Chopraya Praklang (Hon). However the suite does not represent the whole story but only portrayed the escape of Sming Pra Ram. The plot of the story was that King Montien Tong once made a promise to Sming Pra Ram to not call him as "captive", failing which Saming Pra Ram would immediately flee to Honsawadee. But after hearing King Montientong calling Sming Pra Ram's son "a captive's child", He decided to make his escape straight away. The suite later become the model for Pipat Duekdamban and other non-theatrical ensemble performances, vocally and instrumentally.

The Mon-accented vocal melodies of Rājādhirāt play by Fine Arts Department are based on the already existing repertoires. In case there is no assigned lyrics to any available musical piece, it is composed following Thai music principles. (Pattanee Promsombut, 2015: Interview). The same is applied to Khab Sepha, which is developed to narrate Lakorn Pan Tang's, with respect to the origin of the narrated story, i.e. Thailand, Laos or Mon. And Rājādhirāt play has led to the creation of 
new style of Khab Sepha, known as Sepha Mon, in addition to existing Sepha Thai and Sepha Lao (Jatuporn Seemuang, 2555: 3)

\section{Notation of Mon Rong Hai}

\begin{tabular}{|c|c|c|c|c|c|c|c|}
\hline - FMR & $-M-R$ & -R-R & $---M$ & -R-M & $-F-S$ & -LLL & $-\mathrm{T}-\mathrm{L}$ \\
\hline - FMR & $-M-R$ & $-R-R$ & $---M$ & FMRL & -R-S & --TL & SL-T \\
\hline--- & $---T$ & -TTT & $-T-T$ & -R-M & $-R-T$ & $---\mathrm{L}$ & $---S$ \\
\hline $\begin{array}{l}--- \\
\end{array}$ & $---S$ & -SSS & -S-S & -T-L & -S-M & -DRM & -S-L \\
\hline ---- & $---\mathrm{L}$ & -LLL & -L-L & TR' T'T & LTLL & TLSL & TLR ${ }^{\circ} \mathrm{T}$ \\
\hline$-\mathrm{R}-\mathrm{T}$ & -L-S & -F-S & -L-S & FMRL & RLR M & FMRM & FSFS \\
\hline MFSL & FSFL & MFSL & TLSF & -L-R & $-\mathrm{M}-\mathrm{F}$ & -TLF & -M-R \\
\hline$-T-R$ & $-\mathrm{T}-\mathrm{L}$ & $-S-L$ & RTT'T & -TRL & TLSM & -S-L & LL-S \\
\hline FMRL & RLR M & FMRM & FSFS & $-\mathrm{L}-\mathrm{R}$ & $-\mathrm{M}-\mathrm{F}$ & LTLF & $-\mathrm{M}-\mathrm{R}$ \\
\hline
\end{tabular}

\section{eveloping Musical Repertoires}

There are 5 different types of repertoires used in a Lakorn Pan Tang, i.e. Home Rong, La Rong, Long Rong, Nha Pat and Kred (can be substituted with Nha Pat repertoires when suitable). The term "developing musical repertoires" in this article would deal with the process of musical piece selection and assigning it into a play. The one responsible for such task must be an experienced and knowledgeable musician in the branch of Thai musical pieces. (Chaiya Thangmisri, 2015: Interview). The types of musical repertoires which are developed for the Rājādhirāt Lakorn Pan Tang are Nha Pat and Pleng Kret Repertiores.

1. Nha Pat repertoires are those used to accompany theatrical performances such as Khon and play to supplement an expression or action of a character. The Nha Pat repertoires used in Rājādhirāt Lakorn Pan Tang are Choed, Od, Rua, La, Phya Doen.

2. Kret repertoires are the group of Song Chan or Chan Dio songs that possess idiomatic character such as Thai, Lao, Khmer, Burmese, Mon or Chinese accented. Besides theatrical use, these repertoires can be played for entertainment as well. Here in this article, these repertoires will be referred to altogether as "Pleng Samniang Pasa" or the idiomatic repertoires. 4 accents of idiomatic repertoires are used in Rājādhirāt Lakorn Pan Tang, i.e. Thai, Burmese, Chinese and Mon. The specific accent of each idiomatic musical piece is played differently according to the ethnic background of a character. For the Mon-accented repertoires, in particular, in order to add make the accent more pronounced, some Mon-influenced musical instruments are played along such as Gong Mon, Pi Mon, Ta Pone Mon and Poeng Mang Kok.

It is found that there are number of Mon-accented repertoires assigned to Rājādhirāt play, both vocal and instrumental. Each musical piece is played in different situations according to the story and character's emotion, e.g. courage, lamenting, sorrow, romance and grief. The selection of musical piece must 
importantly depend on the ethnic background and emotion of a character at any given time so that musical pieces are appropriately applied.

The understanding of idiomatic repertoires requires Thai musician's ability to organize musical pieces into categories. The practice is well comprehended by those who are familiar with Thai musical cultures. But to those who are cultural outsiders, the concept is rather something unfathomable. However, this article will define Idiomatic repertoires or PLENG PA SA as "a type of Thai musical repertoires which are composed with an attempt to imitate the musical forms of other nations, which are recognized among Thai musicians." Some pieces are composed out of sheer memory in an endeavor to copy the melodic and rhythmic features of other nation's music such as China, Laos, Mon, Khmer, KAEK, FARANG, YUAN, Japan, and performed with Thai traditional music instruments. With respect to this, Terry E. Miller (2008:152) also elaborated the term SAMNIANG (accent) in Thai traditional music as

"...These works are considered to have a national accent (Samniang), and it has long been customary to play many of them as a suite, awk Pasa ("Out of Language, or "Language Suite"). The original tune for a composition so designated may or may not have come from the culture denoted but is at least considered to be in the style of that culture. The most common tunes are "Lao", "Khamen"(Cambodian), "Khaek" (Muslim, Malay, or Indian), "Mawn" (Mon), "Khaek-Mawn," "Jin" (China), and "Phama" (Burma), but others are possible, including "Jawa"(Java), "Yipun" (Japan), "Farang" (Western), and "Yuan" (Vietnam). The "exotic" quality of each composition is made clear through the use of specific percussion, often from the culture invoked, and a specific drum pattern.

\section{Analysis of meaning and expression of Mon-accented Thai traditional repertoires in Rājādhirāt Literature.}

The Analysis of Rājādhirāt-influenced musical repertoires is carried out to categorize Mon-accented Thai traditional repertoires to show how each Monaccented Thai traditional repertoires are applied in 2 widely-accepted significant musical works, which are

1. Rājādhirāt Suie (Tab Rājādhirāt) by Prince Narisara Nuvadtivongs (1894)

2. Rājādhirāt Play: Sming Pra Ram A Sa by the Fine Arts Department (1952).

\section{Mon-accented Thai traditional repertoires in the Rājādhirāt suite of Prince Narisara Nuvadtivongs.}

The arrangement of musical repertoires for the Rājādhirāt Suite has been done along with certain new creations. These are:

1. Conversion play script from prose to poem to be used as lyrics.

2. Selection of vocal repertoires from Mon and Burmese accented repertoires that correspond to character's emotion. These are.

- Pama He (พม่าเห่)

- Mon Ram Dab(มอญรำดาบ)

-'Ta Now (ตะนาว)

- Mon Rong Hai (มอญร้องไห้) for unveiling of the King of Ava in the throne hall for Sming Pra Ram's sorrow, frustration for Saming Pra Ram's touching emotion. for Sming Pra Ram's overwhelmingly agony. 
3. Selection of Nha Pat repertoires to accompany character's action. These are -Samoe (เสมอ) played during the King of Ava's return to throne

- Phya Doen (พญาเดิน) played during Sming Pra Ram's journey

- Od Mon (โอดมอญ) played when Sming Pra Ram cries during his journey

-Choed (เชิด) played during Sming Pra Ram's horse ride return to Hamsavatī

Consider the assigned repertoires in the suite, it is found that the composer chose 2 accents of idiomatic repertoires for the Rājādhirāt suite, i.e. Burmese and Mon accented repertoires, which is in accordance with Sming Pra Ram's ethnic background. In this episode, the story emphasizes mainly at presenting the role, feelings and emotion of Sming Pra Ram, which is why the number of Monaccented repertoires are greater than the other.

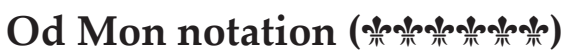

\begin{tabular}{|c|c|c|c|c|c|c|c|}
\hline -SLT & -R-M & $---S$ & $---\mathrm{L}$ & --SM & SM-- & RMSL & TS-L \\
\hline ---T & $-\mathrm{R}^{\circ} \quad-$ & -SSS & LT-L & --SM & SM-- & RMSL & TS-L \\
\hline$---T$ & $-\mathrm{R}^{\circ} \quad--$ & -SSS & LT-L & $-D^{\circ} \quad-R^{\circ}$ & -M" -- & $-\mathrm{R}^{*} \quad-\mathrm{D}^{\circ}$ & -T-L \\
\hline$-\mathrm{R}^{\circ} \quad-\mathrm{M}^{*}$ & $-\mathrm{R}^{*}-\mathrm{T}^{*}$ & $---\mathrm{L}$ & $---S$ & & & & \\
\hline
\end{tabular}

The notation of Od Mon above has been rearranged from an original Nha Pat piece, Od, to particularly accompany a Mon character's sorrow and grief (Chaiya Thangmisri, 2558: interview)

Od Thai notation ( $\square \square \square$ )

\begin{tabular}{|c|c|c|c|c|c|c|c|}
\hline -SLT & -R-M & $---S$ & $---\mathrm{L}$ & -LLL & -S-L & -LLL & -S-L \\
\hline -LLL & -S-L & -S-M & -S-L & -TTT & -L-S & -L-T & TT-L \\
\hline -M-L & -S-M & -DRM & -S-L & -TTT & -L-S & -L-T & TT-L \\
\hline$-\mathrm{R}^{\circ} \quad-\mathrm{M}^{\prime}$ & $-\mathrm{R}^{*} \quad-\mathrm{T}^{\prime}$ & $---\mathrm{L}$ & $---S$ & & & & \\
\hline
\end{tabular}

\section{Mon-accented Thai traditional music repertoires in Rājādhirāt Lakorn Pan Tang: Sming Pra Ram A Sa by the Fine Arts Department.}

The Rājādhirāt Lakorn Pan Tang, created to perform at Silpakorn (Fine Arts) theatre in 1952, consists of 6 different scenes with different characters of Burmese, Chinese and Mon origin. The summary of the play is that when the Chinese troops came knocking at Burma's door, the former were apparently invincible. Sming Pra Ram, being held as Mon prisoner in Burma, volunteered to fight the battle under the condition that, should he win the battle, he must be entitled the Viceroy and that the King of Ava must marry him with his daughter.

The repertoires in the play consists of Nha Pat repertoires, i.e. Phya Doen, Choed, Rua, Sa Moe Mon, Sa Moe Pama, Wien Tien, Od Mon, Idiomatic repertoires, i.e. Burmese-accented, Chinese-accented, Mon-accented. The role and function of these repertoires can be organized into 2 groups:

Group 1 vocal repertoires Mon Ram Dab (SONG CHAN), Mon Ram Dab (CHAN DIO), Song Ku Mar, Chau Pum Riang, Pha Phok (CHAN DIO), Khaek Mon Bang Khun Prom, Ta La Mae Sri, Mon Oi Ing, Ma Ta Bae, Lohm Mon, Mon Yaad Le, 
Mon Ta Now and Mon Rong Hai.

Group 2 Instrumental repertoires Pleng Rew Mon, Plai Ram Mon, Yog Ta Lum, Sa Moe Mon, Od Mon and Dao Kra Jai.

Table of Character's-emotion-wise repertoires

\begin{tabular}{|c|c|c|}
\hline \multicolumn{2}{|l|}{ Reflective repertoires } & \multirow{2}{*}{$\begin{array}{l}\text { Nha Pat repertoires } \\
\text { Occasion of Application }\end{array}$} \\
\hline Positive Emotion & Negative Emotion & \\
\hline $\begin{array}{l}\text { Mon Ram Dab (มอญรำดาบ) - } \\
\text { Courage } \\
\text { Song Ku Mar (สองกุมาร) - } \\
\text { Contemplation ahead of war } \\
\text { Chau Pum Rian (เจ้าพุมเรียง) } \\
\text { - turing situation around } \\
\text { during battle } \\
\text { Pha Phok Chan Dio (ผ้าโพก } \\
\text { ชั้นเดียว)- Determination, } \\
\text { Confrontation, Challenge } \\
\text { Kaek Mon Bang Khun } \\
\text { Prom (แขกมอญบางขุนพรหม) - } \\
\text { Certainty, Negotiation } \\
\text { Ta La Mae Sri (ตะละแม่ศรี) - } \\
\text { Feminity (shy) } \\
\text { Mon Oi Ing- Persuasion, } \\
\text { Revelation of feeling } \\
\text { Ma Ta Bae (มะตะแบ)- } \\
\text { Uneasiness Uncertainty } \\
\text { Lohm Mon (โลมมอญ) - } \\
\text { Romance }\end{array}$ & $\begin{array}{l}\text { Mon Ram Dab (มอญรำดาบ) - } \\
\text { Anger, Annoyance } \\
\text { Mon Yaad Le (มอญยาดเล้) - } \\
\text { Sorrow } \\
\text { Mon Ta Now (มอญตะนาว) - } \\
\text { Sorrow, Effusive } \\
\text { Mon Ram Dab (มอญรำดาบ) - } \\
\text { Sorrow, Bereft from loved } \\
\text { one. }\end{array}$ & $\begin{array}{l}\text { Phya Doen (พญาเดิน) - } \\
\text { travelling of noble ones } \\
\text { Choed (เชิด) - Fighting } \\
\text { Rua (รัว) - Highlight during } \\
\text { fight } \\
\text { Wien Tien (เวียนเทียน) - } \\
\text { Auspicious ritual } \\
\text { Sa Moe Mon (เสมอมอญ) - } \\
\text { Sming Pra Ram walk-in } \\
\text { Od Mon (โอดมอญ) - Sming } \\
\text { Pra Ram's sorrow }\end{array}$ \\
\hline
\end{tabular}

\section{CONCLUSION}

Rājādhirāt is the name of a Mon King who lived during 1385 - 1423 A.D. It is a historical series of events that was written in palm books since the Queen Cheng So Bu (1453 - 1472 A.D.) and the King Dharmaceti (1472 - 1492 A.D.). Later on in the reign of King Bayinnaung (1550 - 1581 A.D.), Phya Thala rearranged the Chronicles of the Mon and translated them into a more subtle Burmese language version, called "RAZADARIT AYEDAWPON". This, very documents become the model of Burmese

literature from which countless copies and translations had been made, including Burmese and Mon language. When it was introduced to Thailand, the literature was again selected as one of the royal literatures during King Rama I and was translated to Thai language by Chao Phraya Phra Khlang (Hon).

Thai version of Rājādhirāt by Chao Phraya Phra Khlang (Hon), was further developed and modified for Thai theatrical play (Lakorn Pan Tang) and music (a musical suite), by adapting, extending, abridging and decorating the original version. When the Thai theatrical play were advancing, so were Thai traditional 
music. Numerous existing Mon-accented repertoires were revised and was assigned accordingly to the Rājādhirāt play to effectively portray as much emotion of a character in any scene as possible. These revised Mon-accented repertoires come in 2 forms, i.e. vocal and instrumental repertoires, both of which are played along with Mon-influenced musical instruments.

Combing every issue aforementioned, the influence of Rājādhirāt literature on Mon-accented Thai traditional repertoires, therefore, reflects the evolution of Thai traditional music in theatrical field - in this case Lakorn Pan Tang. As Monaccented repertoires, found in Rājādhirāt Lakorn Pan Tang, underwent certain musical processes, i.e. assignment of Mon-accented repertoires to accompany characters of Mon origin, the Mon-accented are thus conserved and therefore remain active within Thai musical culture.

\section{REFERENCES}

Fine Arts Departmnt. (1952). Rājādhirāt Play: Sming Pra Ram A Sa. n.d. . (1969). Rājādhirāt by Chao Phraya Phra Khlang (Hon). Bangkok: Silpabanagar.

Bussaba Trakulsajjawatra. (1986). Analytical Study of Rājādhirāt Literature by Chao Phraya Phra Khlang (Hon). Thesis M.A. (Thai language), Graduate Studies, Chulalongkorn University.

Chakrit Duangpatra. (2001). Theatrical Literature. Khon Kaen: Klang Nana Vidya Press.

Jatuporn Seemuang. (2012). Idiomatic Expressions in Sepha: A Study of Original Idiomatic and Experiment of New Idiomatic Expression in Sepha. Thesis Ph.D. (Music). Graduate Studies, Mahidol University.

Emmanuel Guillon. (1999). The Mons: a civilization of Southeast Asia. Translated and Edited by James V. Di Crocco. Siam Society: Bangkok.

Holliday,R. (1969). "Immigration of the Mons into Siam". Journal of The Siam Society. Volume 10. Kraus Reprint, pp. 1-15.

Jotidharmasundar, Prakhru. (2006).Sacred Chedi's and Shrines for Mon People. Bangkok: Mon Language Center, Awudh Vikasitaram Temple.

Montri Tramote and Vichian Kulatand. (1980). Listening and Understanding Thai Music. Bangkok: Thai Kasem Press.

Nai Pan Hla. (2011).Archaeological aspects of Pyu Mon Myanmar. Yangon.Thin Sapay. Saowanit Wingwon. (2012). Theatrical Literature. Bangkok: Shakti Sobha Press.

Terry E. Miller and Sean Williams. (2008). The Garland Handbook of Southeast Asian Music. Routledge: UK.

Virach Niyomdharm (2009). Rājādhirāt Yuddhna by Phya Thala. Institute of Asian Studies, Chulalongkorn University, Supported by East Asia Department, Ministry of Foreign Affair.

\section{Interviews}

Chaiya Thangmisri. (17 ${ }^{\text {th }}$ August 2015). Interview. Music Division, Fine Arts Department. Bangkok.

Pattanee Promsombut. (18 $8^{\text {th }}$ July 2015). Interview. Music Division, Fine Arts Department. Bangkok.

Pisan Boonphook. (25 $5^{\text {th }}$ June 2015). Interview. Regional Center for Archeology and Visual Arts, a SEAMEO - SPAFA's Organization.

Virach Niyomdharma. (2nd August 2013). Interview. Assistant Professor. Center for Burmese Studies, Faculty of Humanities, Naresuan University. 